\title{
JA.466 ROOT EXUDATION OF SORGHUM AND UTILIZATION OF EXUDATES BY NITROGEN-FIXING BACTERIA
}

\author{
J. A. Kipr-Nol r." []. K. AVAl-akKl and P. J. Dart' \\ Cereal Microbiology Division. Internalional Crops Research Institute for the Semi-arid Tropics \\ (ICRISAT), Patancheru P. (). Andhra Pradesh 502 ,34. India \\ (Accepted 14 April 1485)
}

\begin{abstract}
Summary-Qualitative differences in the soluble exudates of seedlings of different sorghum (Sorghum hicoler) genotypes were demonstrated by variation in growth of diazotrophic bacteria in exudalecontaining media. Isolates varied in their ability os utilize the exudate from a given genolype. Variation in the amounts of soluble carbon exuded hy axenically grown seedlings of the different genotypes was also observed. However, the variation in plant-associated acetylene reduction activity of one strain. faspirillum lipoferum $4 \mathrm{ABL}$. did not reflect the variation in exudation of soluble organic carbon, nor the variation in ability of the isolate to utilize the exudates in semsi-solid media.
\end{abstract}

\section{INTRODUICTION}

There are numerous reports of plant responses to inoculation with nitrogen-fixing bacteria (Okon. 1984). Whether these responses result from a direct improvement of nitrogen nutrition through fixation. from the effects of plant hormones produced hy the hacteria, or from the effects of the inoculum on other rhizosphere organisms, such as the inhibition of minor pathogens, is still uncertain. The survival and competitive ability of introduced microorganisms in the plant rhizosphere are dependent not only on numerous abiotic factors such as temperature, $\mathrm{pH}$, moisture and oxygen tension: but also on the types and numbers of other organisms present and the quality and quantity of root exudates and plant debris available as carbon and energy sources.

In inoculation experiments host plant bacterial strain interactions have been observed by a number of workers and in a few cases been related to root exudates. Neal and Larson (1976) reported the stim. ulation of a $N_{2}$-fixing Bucillus sp. in the rhizosphere of certain wheat lines: and there are differences in the establishment of Azospirillum strains in wheat roots (Baidani et al., 1983) and in the rhizosphere of Zeu mays (O'Hara et al., 1981). Azospirillum, as compared to Azotobacter, Klebsiella, Rhizobium, Pseudomonas and Escherichia, is preferentially absorbed to pearl millet and guinea grass roots (Umali-Garcia et al. 1980). Substances in the root exudates bind to Azospirillum and promote this absorption.

Differences in associative $\mathrm{N}$, fixation between genotypes of various grasses and cereals have been demonstrated using $\mathrm{C}_{2} \mathrm{H}_{2}$ reduction (Neyra and Dobereiner, 1977: Dart and Wani, 1982). Cultivars of sorghum have demonstrated this variability at the seedling stage when grown in tubes, in pots in the

-†Present addresses: “CIAT, Apartado Acreo 6713, Cali, Colombia. South America and + Research School of Biological Sciences, GPO Box 475. Australian National University, Canberra City, ACT 2601, Australia. glasshouse, and in ficld experiments (ICRISAT, 198.3). In this study we have examined the exudation of soluble carbon from seedlings of 6 sorghum genotypes and compared exudation, plant growth and plant associated nitrogenase activity in microbiologically defined conditions. As host cultivar bacterial strain interactions have been observed in field inoculation experiments we have also examined the utilization of soluble root exudates by different $\mathrm{N}_{2}$-fixing bacteria.

\section{MATERIALS AND METHODS}

\section{Exudate collection and concentration}

Seeds of four Sorghum hicolor (L.) Moench lines (IS 300)3, (SH 5, IS 2333, IS 15165) were surface sterilized as follows: they were first washed (on a rotary shaker) in $3.5^{\circ}{ }_{v} \mathrm{H}_{2} \mathrm{O}_{2}\left(\mathrm{v} / \mathrm{v}\right.$ with $\mathrm{H}_{2} \mathrm{O}$ ) for $1.5 \mathrm{~h}$, rinsed in sterile water, washed for $2 \mathrm{~h}$ in $2^{\prime \prime}$; chlorox $(\mathrm{v} / \mathrm{v} \mathrm{H}, \mathrm{O})$, and then rinsed again in sterile water. The seeds were put on nutrient agar plates at $33^{\prime \prime} \mathrm{C}$ to germinate and to check for contamination. After $48 \mathrm{~h}$, seedlings were transferred $(4 /$ tube) onto stainless steel wire mesh supports in cotton-plugged, sterile tubes $(25 \times 200 \mathrm{~mm})$ containing $20 \mathrm{ml}$ distilled water. Plants were held in a glasshouse with the temperature ranging from $21^{\circ} \mathrm{C}$ at night to $37 . \mathrm{C}$ around noon. Every 2 days for 8 days, the tubes were shaken, the medium decanted and fresh sterile water added. Non-contaminated media samples were frozen and then lyophilized to concentrate to about $0.05(5 \%)$ the volume.

\section{Growth of bacteria in exudate media}

Semi-solid $(0.175 \%$ agar $w / v)$ salts medium was prepared as follows: $0.5 \mathrm{~g} \quad \mathrm{~K}_{2} \mathrm{HPO}_{4}, \quad 0.5 \mathrm{~g}$ $\mathrm{MgSO}_{4} \cdot 7 \mathrm{H}_{2} \mathrm{O}, 0.1 \mathrm{~g} \mathrm{NaCl}, 2 \mathrm{mg} \mathrm{Na} \mathrm{MoO}_{4} \cdot 2 \mathrm{H}_{2} \mathrm{O}$, $10 \mathrm{mg} \mathrm{MnSO}_{2} \cdot 2 \mathrm{H}_{2} \mathrm{O}, 4 \mathrm{ml}$ of $1.64 \%$ aqueous $\mathrm{Fe}$-EDTA, $20 \mathrm{mg} \mathrm{CaCl}$, water to 11 . After autoclaving and cooling concentrated exudates from the different sorghum lines were added to the semi-solid medium to give a final concentration of $0.4 \mathrm{~g}$ organic- 
Table 1. Oreanic carbon exuded into the culture medium from day 2 to day 9 , and plant root and shoot dry weights on day 9, of axenic seedlings of 6 sorghum genotypes

\begin{tabular}{lccc}
\hline Genotype & $\begin{array}{c}\text { Organic C } \\
\text { (mg/tube) }\end{array}$ & $\begin{array}{c}\text { Root wt } \\
\text { (mg/tube) }\end{array}$ & $\begin{array}{c}\text { Shoot wt } \\
\text { (mg/tube) }\end{array}$ \\
\hline IS 3003 & $9.5(0.42)$ & $29(0.7)$ & $52(1.8)$ \\
IS 2333 & $9.4(0.40)$ & $23(0.6)$ & $32(0.8)$ \\
IS 15165 & $8.4(0.42)$ & $37(0.8)$ & $80(1.3)$ \\
CSV.5 & $6.9(0.46)$ & $25(0.5)$ & $37(1.3)$ \\
CSH.5 & $5.9(0.34)$ & $24(0.6)$ & $42(1.3)$ \\
IS 859 & $5.2(0.30)$ & $15(0.6)$ & $31(0.7)$ \\
\hline
\end{tabular}

Means of 15-28 replications (SE).

Linear correlation coefficients:

organic $C$ vs root $w t r=0.60 \mathrm{NS}$ at $P=0.05$ :

organic $C$ vi shoot $w 1 r=0.38$

\section{DISCUSSION}

Genotypes of sorghum have been shown to support different levels of associated nitrogenase activity. and in inoculation experiments bacterium by cultivar interactions were observed (ICRISAT, 1983). This study was undertaken to determine whether quantitative or qualitative differences in root exudation could be detected which might be responsible for these findings. Variation in the composition of soluble exudate was demonstrated. Diazotrophic bacteria are able to utilize a variety of compounds as carbon and energy sources, but whether the observed differences in this study resulted from variation in the relative amounts of these compounds or to the presence of promoter or inhibitory substances is yet to he determined. By $48 \mathrm{~h}, \mathrm{C}_{2} \mathrm{H}_{2}$ reduction activity had decreased in all cultures and growth had usually ceased indicating substrate deficiency or poor ability of bacteria to utilize some of the exudate. Bacterial cultures 27155, 7ATZ and 480 had very low $\mathrm{C}_{2} \mathrm{H}_{3}$ reduction activity at both $24 \mathrm{~h}$ and $48 \mathrm{~h}$ in IS 2333 exudate media; however, significant growth of these cultures did occur during this period. There must have been either a brief undetected spurt of nitrogenase activity, or these cultures were able to scav- enge some nitrogen from the medium. Bacteria utilized the exudate from a given genotype differentially. Some specificity has been observed both between diazotrophic species and between strains of a given species, in their ability to colonize the roots or rhizosphere of a given cereal. This may be a reflection, at least in part. of the observed differences in ability to utilize the soluble exudates present. Baldani and Dobereiner (1980) proposed some specificity of C4 plants for A. lipoferum over $A$. brasilense. In our experiments $A$. lipoferum strains exhibited the most growth but some of the $A$. brasilense strains also grew well on the exudate media. The non-Azospirillum isolates did not grow well. This was not simply due to an inability to use malate, a possible significant component of the exudates. as the four ICRISAT isolates grew well and exhibited high $\mathrm{C}_{2} \mathrm{H}_{2}$ reduction activity in both sucrose and malate containing media.

This work was restricted to exudates of seedlings but while recognizing that exudates change with plant age and are affected by many factors. seedling studies were thought to be meaningful as sorghum cultivar differences in associated nitrogenase activity (ICRISAT. 1983) and ' $N_{2}$ incorporation into plant tops (Giller et al., 1984) have been observed at the seedling stage. Quantitative differences between genotypes in the exudation of soluble organic compounds were consistently observed (Fig. 2). There was no correlation between the amount of exudate and root or shoot weight (Table 1). Even with replicates of a given cultivar there was little relation $(r<0.50)$ hetween root weight and exudate. This is contrary to the observations of Prikryl and Vancura (1980) with wheat rost exudation. The quantitative measures of exudates under these conditions are most likely an underestimate of those available from seedlings in soil where mechanical forces (Barber and Gunn. 1974), and soil microorganisms (Prikryl and Vancura. 1980: Lee and Gaskins. 1982: Barher and Martin. 1976) play an important role. There is a need for radio-tracer studies, similar to those of Whipps and Lynch (1983) and Beck and Gilmour (1983), using tropical (rather than temperate) grown cereals, to

Tuble 2. Acelylene reduction activity of Azaspirillum lipeferum 4ABL associated with seedlings of o sorghum genotypes

\begin{tabular}{|c|c|c|c|c|}
\hline Genotype & 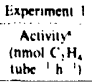 & $\begin{array}{l}\text { Actwity } \\
\text { (nmol } C_{2} \mathrm{H}_{4} \\
\text { tute }{ }^{\prime}{ }^{\prime} \text { ) }\end{array}$ & $\begin{array}{c}\text { Root wi } \\
\text { (mg lube ') }\end{array}$ & $\begin{array}{l}\text { Shoot wt } \\
\text { tmg lube }\end{array}$ \\
\hline $\begin{array}{l}\text { IS } 3003 \\
\text { IS } 2333 \\
\text { IS } 15165 \\
\text { CSV.5 } \\
\text { CSH.5 } \\
\text { IS } 889\end{array}$ & $\begin{array}{r}17(5.2) \\
10(1.7) \\
53(9.0) \\
20(2.3) \\
4(3.2) \\
13(4.9)\end{array}$ & $\begin{array}{l}20 \\
15 \\
32 \\
15 \\
7 \\
8\end{array}$ & $\begin{array}{l}29(2.6) \\
22(0.8) \\
58(1.8) \\
27(1.1) \\
32(1.1) \\
15(0.6)\end{array}$ & $\begin{array}{l}45(3.4) \\
20(1.1) \\
83(2.1) \\
35(2.1) \\
40(4.3) \\
25(1.4)\end{array}$ \\
\hline \multicolumn{5}{|c|}{ 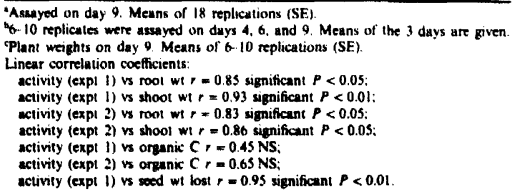 } \\
\hline
\end{tabular}


estimate the potential amounts of substrate available for associative nitrogen fixation. For although there is evidence that some nitrogen-fixing bacteria are present within roots the numbers are small when compared to the rhizosphere populations that utilize exudate and cell debris. (McClung et al., 1983; Giller and Day, 1985).

Sorghum genotypes varied in their ability to sup. port nitrogen fixation by $A$. lipoferum $A \mathrm{ABL}$, but there was no correlation between activity and the amount of soluble exudate measured in axenic systems. The ranking of genotypes for plant associated activity also differed from that for the growth and activity of $4 A B L$ in semi-solid exudate media. For example, IS 15165 and IS 2333 both exhibited high rates of exudation. $\mathrm{C}_{2} \mathrm{H}_{2}$ reduction activity associated with IS 15165 seedlings was high but that associated with IS 2333 seedlings was low, while in exudate media (containing equal organic carbon) the opposite ranking was observed. One possible explanation is that $4 \mathrm{ABL}$ alters the exudation pattern of the two cultivars differentially. In support of this there was little difference in the root weights of IS 2333 grown axenically and in the presence of $4 \mathrm{ABL}$, while the root weight of IS 15165 was greater in the presence of $4 \mathrm{ABL}$ suggesting that the bacterium had stimulated carbon flow to and through the root system. However, for uninoculated plants, no correlation was observed between root weight of different cultivars and the ainount of soluble exudate. A second explanation for the different rankings is that the nonsoluble, non-diffusible exudates are more important in determining plant associated growth and $\mathrm{C}_{2} \mathrm{H}_{2}$ reduction activity. However, in the absence of other organisms which might al least partially break down the complex polysaccharides it is uncertain whether much of the non-diffusible material would be accessible to $4 \mathrm{ABL}$.

One implication of the different genotype rankings between synthetic media and plant culture systems is that there may be little profit in screening bacterial isolates for potential rhizosphere activity by measuring their growth and $\mathrm{C}_{2} \mathrm{H}_{2}$ reduction activity in I synthetic media (even root exudate containing media). It would be interesting to compare the relationship between root exudates and root extracts in supporting bacterial growth.

Varying inoculation responses of crops to diazotrophic bacteria have been observed by many workers; however before consistent beneficial effects can be expected a greater understanding of the plant rhizosphere nitrogen-fixing bacteria association is required. Our study has clearly demonstrated variation in amounts and composition of root exudates, but the relationship between exudation and bacterial growth and $\mathrm{C}_{2} \mathrm{H}_{2}$ reduction activity is not simple and needs further investigation.

\section{REFERENCES}

Baldani V. L. D. and Dobereiner J. (1980) Host plant specificity in the infection of cereals with Azospirillum spp. Soil Biology \& Biochemistry 12, 433-439.
Baidani V. L. D., Baldani J. I. and Dobereiner J. (1983) Effects of Azospirillum inoculation on root infection and nitrogen incorporation in wheat. Canadian Journal of Microbiology 29. 924-929.

Barber D. A. and Gunn K. B. (1974) The effect of mechanical forces on the exudation of organic substances by the roots of cereal plants grown under sterile conditions. New Phytologist 73, 39-45,

Burber D. A. and Martin J. K. (1976) The release of organic substances by cereal roots into soil. New Phytologist 76. 69-80.

Beck S. M. and Gilmour C. M. (1983) Rule of wheat ront exudates in associative nitrogen fixation. Soil Biolugy a Biochemistry 15, 33-38.

Dart P. J. and Wani S. P. (1982) Non-symbiotic nitrogen fixation and soil fertility. In Non-Symbiotic Nitrogen Fixation and Organic Matter in Tropics-Transactions of the 12th International Congress of Soil Science, Vol. 2, pp. 3-27, February 1982, New Delhi.

Fahraeus G. (1957) The infection of clover hairs by nodule bacteria studied by a simple glass slide technique. Journul of General Microbiology 16, 374-381.

Giller K. E. and Day J. M. (1985) Nitrogen fixation in the rhizosphere: significance in natural and agricultural systems. In Ecological Interactions in Soil: Plants, Microbes and Animals (A. H. Fitter, D. Atkinson, D. J. Read and M. B. Usher, Eds), pp. 127-147. Blackwell. Oxford.

Giller K. E., Day J. M., Dart P. J. and Wani S. P. (1984) A methed for measuring the transfer of fixed nitrogen from free-living bacteria to higher plants using ${ }^{15} \mathrm{~N}_{2}$. Journal of Microbiological Methods 2, 307-316.

ICRISAT (International Crops Research Institute for the Semi-Arid Tropics) (1983). Patancheru, A. P., India, pp. 4.7-47,

Johnson M. J. (1949) A rapid micromethod for estimation of non-volatile organic matter. Journal of Biological Chemistry 181, 707-711.

Lee K. J. and Gaskins M. H. (1982) Increased root exudation of ${ }^{14} \mathrm{C}$-compounds by sorghum seedlings inoculated with nitrogen-fixing bacteria. Plant and Soil 69. 391-399.

McClung C R., van Berkum P., Davis R. E. and Sloger C. (1983) Enumeration and localization of $\mathrm{N}_{2}$-fixing bacteria associated with roots of Spartina altenifiora Loisel. Applied and Environmental Microhiology 45, 1914 1920.

Neal J. L. and Larson R. I. (1976) Acetylene reduction by bacteria isolated from the thizosphere of wheat. Soil Biology \& Biochemistry 8, 151-156.

Neyra C. A and Dobereiner J. (1977) Nitrogen fixation in grasses. Aduances in Agronomy 29, 1-38.

O'Hara G. W., Davey M. R. and Lucas J. A. (1981) Effect of inoculation of Zea mays with Azospirillum brasilense strains under temperate conditions. Canadian Journal of Microbiology 27, 871-877.

Okon Y. (1984) Response of cereyl and forage grasses to inoculation with $\mathrm{N}_{2}$-fixing bacteria. In Aduances in Nitrogen Fixation Research (C. Veeger and W. E. Newton, Eds), pp. 303-309. Pudoc, Wageningen.

Prikryl Z. and Vancura C. (1980) Root exudales of plants VI. Wheat root exudation as dependent on growth, concentration gradient of exudates and the presence of bacteria. Plant and Soil 57, 69-83.

Umali-Garcia M., Hubbel] D. H., Gaskins M. H. and Dazzo F. B. (1980) Association of Azospirillum with grass roots. Applied and Environmental Microbiology 39 , 219-226.

Whipps J. M. and Lynch J. M. (1983) Substrate flow and utilization in the rhizosphere of cereals. New Phytologist 95, $605-623$. 